\title{
Peningkatan Pengetahuan Masyarakat dalam Penerapan Protokol Kesehatan melalui Edukasi Berbasis Media Online
}

\author{
Increasing Public Knowledge in Implementing Health Protocols through Online Media-Based \\ Education
}

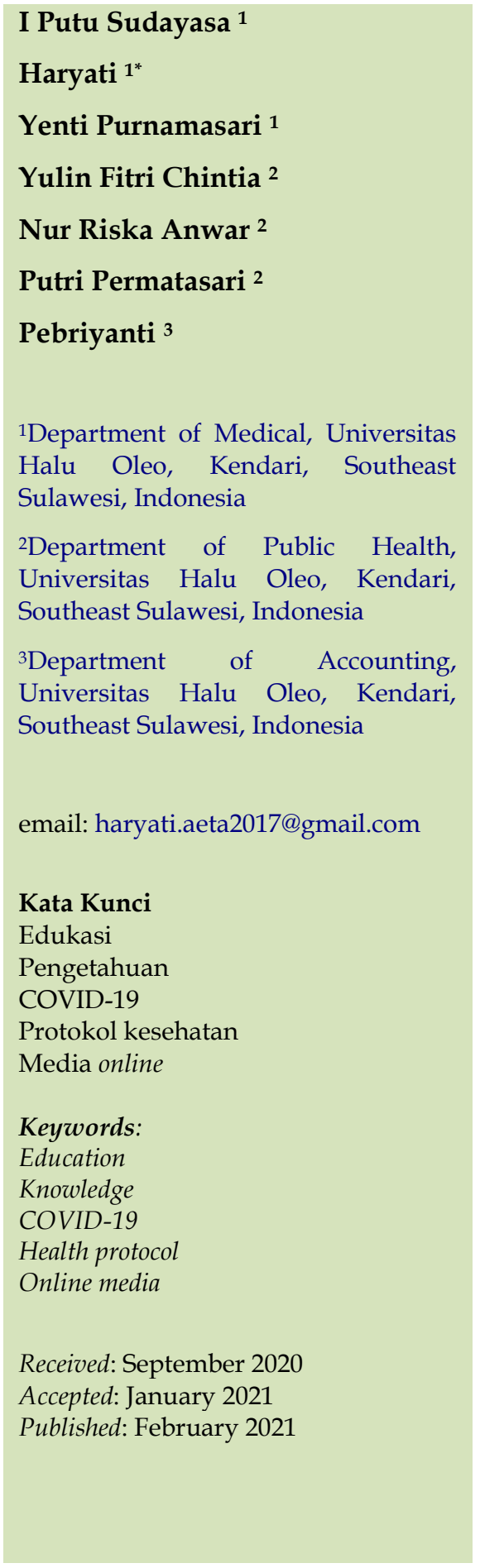

\begin{abstract}
Abstrak
Berbagai upaya pencegahan dan pengendalian COVID-19 secara masif dilakukan oleh pemerintah Indonesia. Penerapan new normal pasca pandemi COVID-19 telah mendorong masyarakat beraktivitas seperti sediakala dengan kewajiban menerapkan protokol kesehatan yang ketat. Namun demikian, angka kejadian COVID-19 di Indonesia masih terus meningkat, demikian pula dengan Kabupaten Konawe sebagai kabupaten dengan laporan kasus positif COVID-19 yang pertama di Sulawesi Tenggara dan saat ini memiliki enam kecamatan dengan status zona merah. Hal ini dikarenakan masih banyak masyarakat yang belum secara sadar melaksanakan himbauan pemerintah dalam menerapkan protokol kesehatan. Pengabdian kepada masyarakat ini bertujuan untuk meningkatkan pengetahuan masyarakat dalam upaya pengendalian COVID-19 melalui penerapan protokol kesehatan. Kegiatan edukasi dilakukan daring melalui media online meliputi konferensi video berupa webminar melalui google meet yang diikuti oleh 86 peserta, siaran langsung pada media sosial facebook dan Instagram, penyiaran video edukasi pada saluran TV lokal, serta melakukan kegiatan luring berupa pemasangan poster edukasi. Edukasi melalui media online merupakan salah satu penggunaan teknologi internet serta jangkauannya luas dan dapat menjadi solusi bagi edukasi di masa pandemi COVID-19. Hasil analisis menunjukkan bahwa edukasi melalui media online efektif meningkatkan pengetahuan masyarakat terkait pengendalian COVID-19 dan penerapan protokol kesehatan di era new normal.
\end{abstract}

\begin{abstract}
The Indonesian government has made various efforts to prevent and control COVID-19. Implementing the new normal after the COVID-19 pandemic has encouraged people to do activities as before, with the obligation to implement strict health protocols. However, the incidence of COVID-19 in Indonesia continues to increase, as is Konawe Regency as the district with the first positive case report of COVID-19 in Southeast Sulawesi and currently has six sub-districts with red zone status. This is because many people are not aware of carrying out the government's appeal in implementing health protocols. This community service aims to increase public knowledge in efforts to control COVID-19 by applying health protocols. Educational activities carried out online through online media include video conferencing in the form of a webminar through Google Meet was attended by 86 participants, live streaming on social media Facebook and Instagram, broadcasting educational videos on local TV channels, and conducting offline activities in the form of installing educational posters. Education through online media is one of the uses of internet technology, and its reach is wide and can be a solution for education during the COVID-19 pandemic. The analysis results show that education through online media effectively increases public knowledge regarding COVID-19 and the application of health protocols in the normal new era.
\end{abstract}




\section{PENDAHULUAN}

Penyebaran Corona Virus (COVID-19) di Indonesia dengan jumlah kasus dan/ atau jumlah kematian yang terus meningkat telah berdampak luas terhadap berbagai dimensi kehidupan masyarakat di Indonesia. Berbagai upaya pencegahan dan pengendalian COVID19 telah secara masif dilakukan oleh pemerintah. Masa tanggap darurat penanganan COVID-19 telah dilaksanakan sejak awal Maret 2020, kemudian dilanjutkan dengan modifikasi kebijakan karantina wilayah menjadi Pembatasan Sosial Berskala Besar (PSBB) pada 10 April 2020 di Jakarta yang kemudian disusul wilayah lain dalam lingkup provinsi, kabupaten, atau kota yang menunjukkan kecenderungan peningkatan kasus secara signifikan. Namun demikian, setelah 3 bulan melewati masa tanggap darurat dan PSBB, pemerintah Indonesia mulai menjajaki penerapan kehidupan normal yang baru (new normal) dan melonggarkan PSBB karena dampaknya terhadap sosial ekonomi masyarakat Indonesia (Muhyiddin, 2020).

Penerapan new normal atau kenormalan baru di Indonesia diatur dalam Keputusan Menteri Kesehatan Nomor HK.01.07/MENKES/328/2020 tentang Panduan Pencegahan dan Pengendalian COVID-19 di Tempat Kerja Perkantoran dan Industri dalam Usaha Mendukung Keberlangsungan pada Situasi Pandemi yang melanda dunia termasuk Indonesia saat ini (Kresna \& Ahyar, 2020). Tahap new normal atau kenormalan baru memiliki makna penyesuaian baru dalam tatanan kehidupan dimana masyarakat hidup berdampingan di tengah-tengah virus yang belum ditemukan vaksinnya. New normal merupakan langkah percepatan penanganan COVID-19 dalam bidang kesehatan, sosial, dan ekonomi, yang dijalankan dengan mempertimbangkan kesiapan daerah dan hasil riset epidemiologis di wilayah terkait. Prinsip new normal adalah bisa menyesuaikan dengan pola hidup.
Transformasi ini adalah untuk menata kehidupan dan perilaku baru ketika pandemi, yang kemudian akan dibawa terus kedepannya sampai ditemukannya vaksin untuk COVID-19 (Rosidi \& Nurcahyo, 2020).

Kesiapan menghadapi tatanan baru dalam kebiasaan normal baik secara fisik, mental, dan sosial perlu dilakukan terhadap keluarga, masyarakat, dan komunitas (Kementerian Kesehatan Republik Indonesia, 2020). Masyarakat harus tetap melawan penyebaran virus COVID-19 sambil beraktivitas seperti sediakala dengan menerapkan protokol kesehatan yang ketat. Pemerintah menghimbau masyarakat untuk melakukan langkah-langkah pencegahan seperti Pelaksanaan Hidup Bersih dan Sehat (PHBS), sering mencuci tangan menggunakan air mengalir dan sabun atau menggunakan hand sanitizer, selalu menggunakan masker ketika berada di luar rumah atau berada di tempat umum, serta melakukan physical distancing dengan tetap menjaga jarak minimal satu meter.

Sulawesi Tenggara merupakan provinsi yang mendapatkan laporan pasien positif COVID-19 pertama kali pada bulan Maret 2020 yang berasal dari Kabupaten Konawe. Laporan kasus pertama kali didapatkan pada pasien dengan riwayat bepergian keluar daerah kota Kendari atau luar Indonesia. Orang-orang yang memiliki riwayat bepergian keluar daerah, khususnya daerah dengan kejadian COVID-19 merupakan kelompok dengan faktor risiko yang besar untuk terkena virus ini (Kementerian Kesehatan Republik Indonesia, 2020). Jumlah kasus positif di Kabupaten Konawe saat ini terus mengalami peningkatan. Hingga tanggal 20 Juli 2020 terdapat 17 kasus terkonfirmasi positif, 38 Orang Tanpa Gejala (OTG), satu Orang Dalam Perawatan (ODP) dan satu Pasien Dalam Pengawasan (PDP) yang tersebar di enam kecamatan yaitu Kecamatan Unaaha, Abuki, Anggaberi, Wawotobi, Wonggeduku dan Wonggeduku Barat. Keenam kecamatan tersebut dinyatakan sebagai 
daerah zona merah atau daerah yang memiliki kasus positif COVID-19 (Dinas Kesehatan Provinsi Sulawesi Tenggara, 2020).

Upaya pencegahan dan pengendalian COVID-19 terus dilakukan oleh pemerintah, namun jumlah pasien dan korban masih belum bisa ditekan secara signifikan. Masih banyaknya masyarakat yang belum secara sadar melaksanakan himbauan pemerintah serta kesimpangsiuran informasi mengenai protokol kesehatan dan perilaku di era adaptasi kebiasaan baru menjadi salah satu penyebab utama (Ngadiran et al., 2020). Meskipun banyak faktor mempengaruhi perilaku yang berhubungan dengan kesehatan, namun kesadaran risiko untuk membuat perubahan perilaku masyarakat adalah unsur utama untuk meningkatkan kesehatan individu dan status kesehatan masyarakat agar terhindar dari COVID-19 (Sampurno et al., 2020).

Proses adapatasi terhadap kebiasaan baru memerlukan bekal pengetahuan yang baik dan kesiapan infrastruktur yang mendukung pencegahan penularan virus disetiap kegiatan yang melibatkan banyak orang. Pengetahuan yang baik akan membentuk sikap dan tindakan yang positif terhadap isu yang ada, seperti perilaku untuk pencegahan dan pemutusan rantai penularan COVID-19 dan juga kedisipilinan dalam menerapkan protokol kesehatan. Dengan demikian, perlu adanya edukasi atau penyuluhan kesehatan bagi masyarakat terkait strategi dalam menghadapi wabah COVID-19 dan penerapan tatanan hidup baru pasca pandemi.

Edukasi atau penyuluhan merupakan cara untuk menyampaikan informasi sehingga dapat meningkatkan pengetahuan yang pada akhirnya dapat diperoleh perubahan perilaku yang mendukung usaha meningkatkan kualitas kesehatan (Sukesi et al., 2020). Media Pendidikan kesehatan berfungsi membantu dalam proses pendidikan. Media pendidikan menjadi alat saluran untuk menyampaikan informasi tentang kesehatan, karena alat-alat tersebut digunakan untuk mempermudah penerimaan pesan-pesan kesehatan untuk masyarakat. Beberapa media yang umum digunakan dalam pendidikan kesehatan seperti leaflet, booklet, kalender, flip chart, video, dan lain-lain.

Berdasarkan kondisi pasca pandemi saat ini, perlu dihindari kegiatan yang mengumpulkan massa atau berkerumun, sehingga perlu mencari pilihan lain yang tepat untuk melakukan edukasi pencegahan COVID-19 serta penerapan protokol kesehatan. Hasil beberapa penelitian menunjukkan bahwa edukasi melalui media online efektif meningkatkan pengetahuan masyarakat. Selain itu, komunikasi media sosial merupakan komponen mendasar dari banyak strategi promosi kesehatan yang dirancang untuk mengubah perilaku risiko kesehatan (Hanson et al., 2011). Media sosial dapat mempengaruhi perilaku individu dan nilai-nilai komunitas yang turut mendukung lingkungan dan individu sehingga diperlukan untuk mempertahankan kebiasaan atas perilaku untuk sadar kesehatan (Sampurno et al., 2020).

Berdasarkan latar belakang tersebut, tim dosen Universitas Halu Oleo bersama mahasiswa beriniasitif melaksanakan amanat pemerintah melalui pengabdian kepada masyarakat terintegrasi Kuliah Kerja Nyata Tematik berupa kegiatan edukasi berbasis media online terkait pencegahan COVID-19 dan protokol kesehatan sehingga pengendalian COVID-19 dapat tercapai.

\section{METODOLOGI}

Pelaksanaan pengabdian kepada masyarakat ini melibatkan khalayak sasaran yang strategis, meliputi Dinas Kesehatan, Satgas COVID-19, klinisi dari BLUD RS Konawe dan RS COVID-19 Kab. Konawe, akademisi dari perguruan tinggi di Kab. Konawe, serta warga masyarakat luas. Metode yang digunakan dalam 
kegiatan adalah edukasi daring menggunakan media online dan edukasi luring menggunakan poster.

Tahap persiapan dilakukan dengan menginventarisasi permasalahan terkait angka kejadian kasus COVID-19, ketersediaan fasilitas yang mendukung upaya pencegahan COVID-19 dan penerapan protokol kesehatan di Kab. Konawe. Selanjutnya dilakukan pengurusan perijinan kepada pemerintah daerah melalui Wakil Bupati Kab. Konawe. Tim menyusun rencana kerja dengan melakukan koordinasi dengan Dinas Kesehatan dan Satgas COVID-19 Kab. Konawe serta LPPM Universitas Halu Oleo. Pembagian tugas anggota tim dilakukan setelah rencana dan jadwal kegiatan telah disusun dan disepakati bersama, meliputi penetapan metode kegiatan, narasumber pada kegiatan webminar, hari dan tanggal pelaksanaan webminar, topik yang disampaikan, dan media yang digunakan.

Kegiatan pengabdian kepada masyarakat dilaksanakan dalam bentuk edukasi daring dan luring sebagai berikut:

1. Melakukan seminar kesehatan dalam jaringan (webminar) melalui Google Meet dengan tema "Sigap Hadapi New Normal", strategi dan tantangan penerapan new normal bagi perguruan tinggi dan pemerintah daerah Kabupaten Konawe.

2. Penayangan video edukasi berdurasi 6 menit dengan judul pencegahan COVID-19 dan penerapan new normal pada saluran TV lokal.

3. Pemasangan poster edukasi terkait langkah standar cuci tangan menurut WHO, poster tentang pencegahan COVID-19, serta poster tentang penerapan protokol kesehatan untuk menunjang keberhasilan program kegiatan.

Tahap evaluasi dan monitoring dilakukan dengan melibatkan tim pelaksana, Dinas Kesehatan, Satgas COVID-19, Rumah sakit, dan stakeholder yang terkait. Evaluasi kegiatan webminar dilakukan dengan menggunakan kuesioner yang berisi 20 pertanyaan yang mengukur pengetahuan masyarakat terkait COVID-19 dan protokol kesehatan di era new normal.

\section{HASIL DAN PEMBAHASAN}

Pengabdian kepada masyarakat ini dintegrasikan dengan KKN tematik yang pelaksanannya lebih dominan pada kegiatan daring dibandingkan luring. Permasalahan yang telah diidentifikasi berdasarkan data hasil observasi dan wawancara dengan Dinas Kesehatan dan Satgas COVID-19 Kabupaten Konawe telah dikonfirmasikan dengan perangkat pemerintah dan analisis potensi yang ada di Kabupaten Konawe.

Pelaksanaan progam kerja berupa edukasi pencegahan COVID-19 dan penerapan protokol kesehatan yang dilakukan secara daring maupun luring. Edukasi di dalam jaringan dilakukan melalui seminar online. Video konferensi ini menggunakan fasilitas Google Meet yang diikuti oleh 86 peserta yang berasal dari masyarakat umum, mahasiswa, dan akademisi di lingkup Kab. Konawe. Selain itu, kegiatan webminar ini juga disiarkan secara langsung (live streaming) pada media sosial facebook dan Instagram Mbakoy Coffee, salah satu kafe terkenal di Kabupaten Konawe yang akunnya banyak diikuti oleh warga masyarakat Kab. Konawe sehingga menjadi media penyebarluasan informasi yang efektif yang ditunjukkan dengan postingan video pada akun facebook menjangkau 2.556 orang dan 764 tayangan.

Seminar daring atau webminar merupakan suatu bentuk pengajaran dari pakar atau ahli yang berbasis media online yang bertujuan untuk mengedukasi dan menambah wawasan warga masyarakat khususnya di Kabupaten Konawe. Seminar ini diselenggarakan dengan tema "Sigap Hadapi New Normal", strategi dan tantangan penerapan new normal bagi perguruan tinggi dan pemerintah daerah yang dilaksanakan tanggal 11 Juli 2020 selama 2,5 jam yaitu pukul 09.00-12.30 Wita dengan melibatkan narasumber dari unsur pemerintah, 
akademisi, dan klinisi di lingkup Kab. Konawe. Peserta memberikan respon yang positif dan berperan aktif dengan melakukan tanya jawab dan diskusi mengenai upaya pencegahan COVID-19 dan protokol kesehatan.

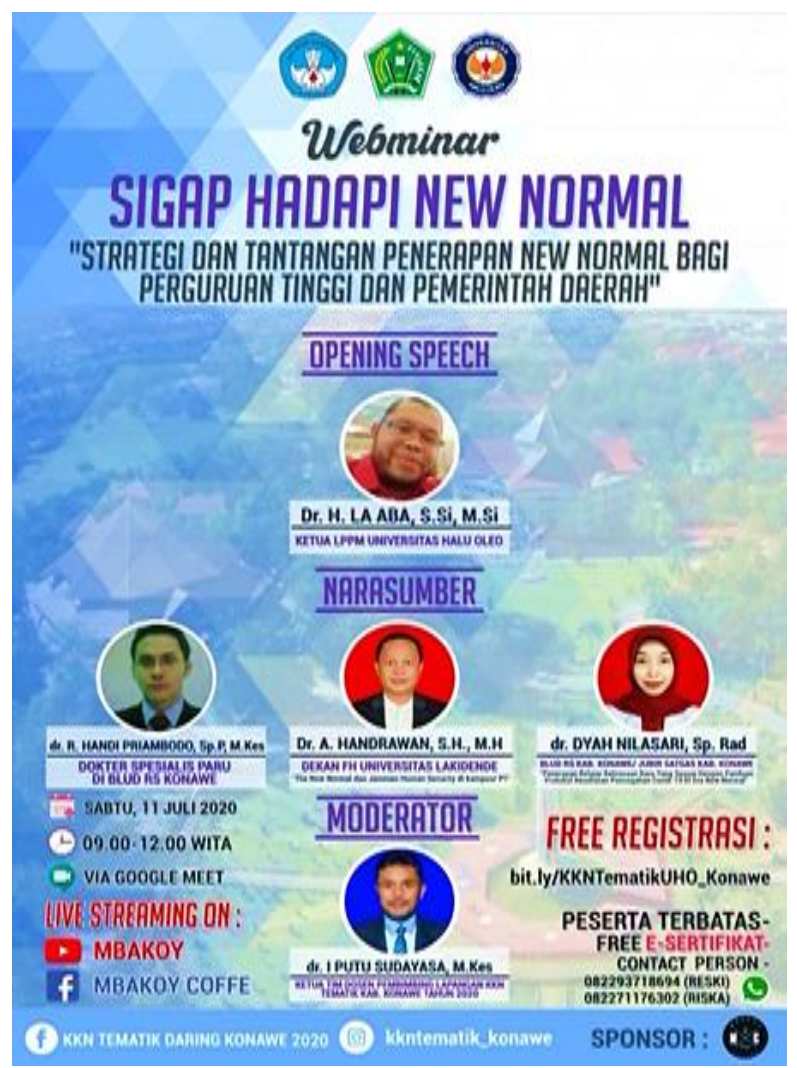

Gambar 1. Poster Kegiatan Webminar “Sigap Hadapi New Normal"

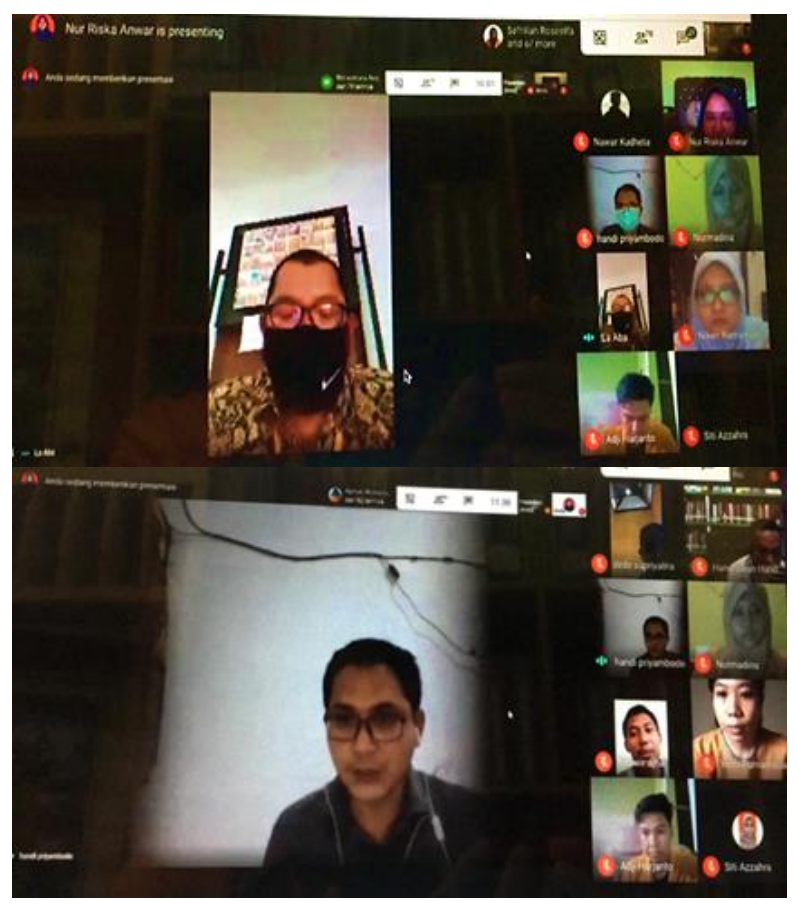

Gambar 2. Penyampaian Materi pada Kegiatan Webminar
Narasumber dari unsur pemerintah merupakan Penanggung Jawab RS COVID-19 Kab. Konawe yang menyampaikan materi seminar dengan judul: Sudah siapkah kita dengan "New Normal"?, narasumber dari unsur akademisi yang merupakan dosen Universitas Lakidende Kab. Konawe membawakan materi seminar dengan judul The new normal dan jaminan human security di Perguruan Tinggi, sedangkan narasumber dari klinisi adalah dokter spesialis radiologi di BLUD RS Konawe dan sekaligus sebagai Juru Bicara Satgas COVID-19 Kab. Konawe yang memberikan materi seminar dengan judul "Panduan Protokol Kesehatan pada era New Normal Life untuk Pendidikan". Narasumber yang terlibat dalam webminar seluruhnya berasal dari Kab. Konawe sehingga keterlibatan mitra sangat besar dalam kegiatan ini. Dengan demikian, kegiatan ini diharapkan dapat membantu program pemerintah dalam mengendalikan kasus COVID-19 dan penerapan protokol kesehatan dengan meningkatkan kemandirian, kesehatan dan kesejahteraan masyarakat, serta memperkuat sinergisme perguruan tinggi dengan stakeholder terkait.

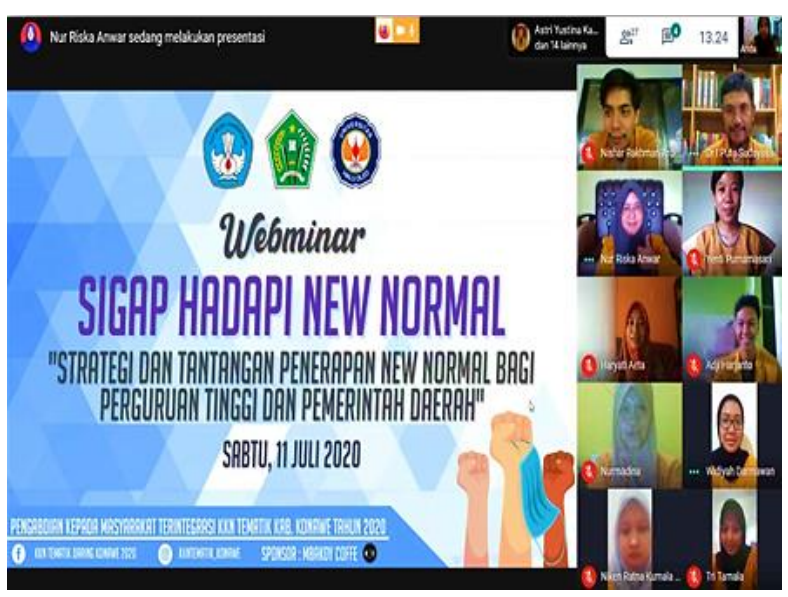

Gambar 3. Video konferensi Webminar menggunakan fasilitas Google Meet 


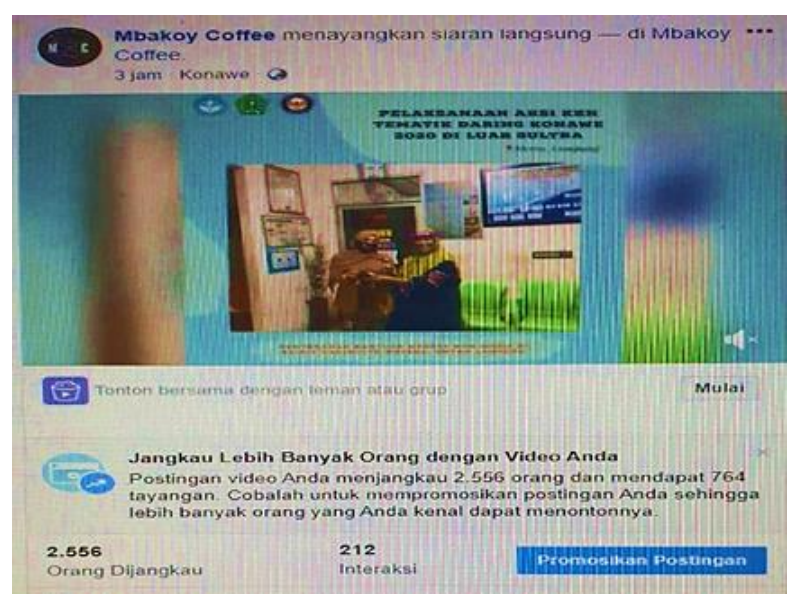

Gambar 4. Live streaming kegiatan Webminar pada media sosial Facebook dan Instagram Mbakoy Coffee

Edukasi kesehatan penting dilakukan sebagai sarana untuk meningkatkan pengetahuan masyarakat. Pengetahuan merupakan domain kognitif yang sangat penting untuk terbentuknya tindakan (overt behavior) (Jumilah et al., 2014). Menurut Notoatmodjo (2003), perilaku yang dilandasi pengetahuan akan lebih langgeng dibandingkan yang tanpa dilandasi pengetahuan. Oleh sebab itu indikator untuk sikap kesehatan juga sejalan dengan pengetahuan kesehatan.

Kegiatan edukasi melalui konferensi video merupakan salah satu cara yang efektif dalam menyebarluaskan informasi kepada masyarakat pada kondisi pandemik saat ini, dimana menjaga jarak (physical distancing) menjadi salah satu poin penting dalam penerapan protokol kesehatan. Penyuluhan kesehatan bagi masyarakat secara online mampu menjangkau lebih luas kalangan masyarakat. Jumlah individu yang dapat dijangkau menjadi kekuatan media yang paling jelas (Hanson et al., 2011). Dengan demikian, media sosial telah menjadi salah satu media untuk edukasi yang dapat dijadikan alternatif sumber jawaban untuk pertanyaan tentang COVID-19 (Sampurno et al., 2020). Selain itu, pemberian edukasi dengan menggunakan media juga dapat berpengaruh meningkatkan sikap responden (Sari et al., 2019). Media edukasi lainnya yang digunakan dalam pengabdian ini adalah video edukasi berdurasi 6 menit mengenai COVID-19 dan penerapan protokol kesehatan yang ditayangkan pada saluran TV lokal selama 30 hari berturut-turut.

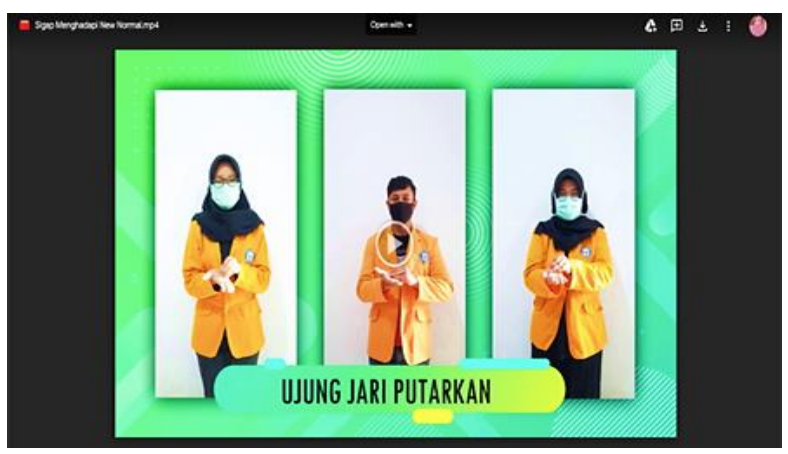

Gambar 5. Screenshot Video Edukasi

Audio Visual merupakan cara pemberian informasi yang sangat baik karena media video mampu diakses lebih dari satu indera manusia, khususnya pendengaran dan penglihatan. Semakin banyak indera yang berperan dalam proses penerimaan pesan, maka penerimaan pesan semakin cepat dan mudah ditangkap. Media audio-visual tidak saja menghasilkan cara belajar yang efektif dalam waktu yang lebih singkat, akan tetapi apa yang diterima melalui media audio-visual lebih lama dan lebih baik tinggal dalam ingatan. Video dalam proses pembelajaran dapat membantu mengingat materi yang telah diberikan hingga 50\% (Adha et al., 2016).

Edukasi diluar jaringan dilakukan dengan menggunakan media poster. Hal ini dilakukan sebagai upaya mengubah perilaku seseorang dari tidak sehat menjadi sehat dengan memberikan informasi (stimulus) secara terus menerus melalui media poster atau leaflet yang merupakan salah satu media cetak yang digunakan untuk promosi kesehatan (Sukesi et al., 2020). Poster edukasi yang diberikan berisi informasi terkait langkah standar cuci tangan menurut $\mathrm{WHO}$ yang dipasang di 25 titik sarana cuci tangan yang ada di fasilitas umum seperti pasar tradisional, sarana olah raga, dan kantor untuk memudahkan masyarakat mengikuti langkahlangkah yang dianjurkan saat mencuci tangan. 


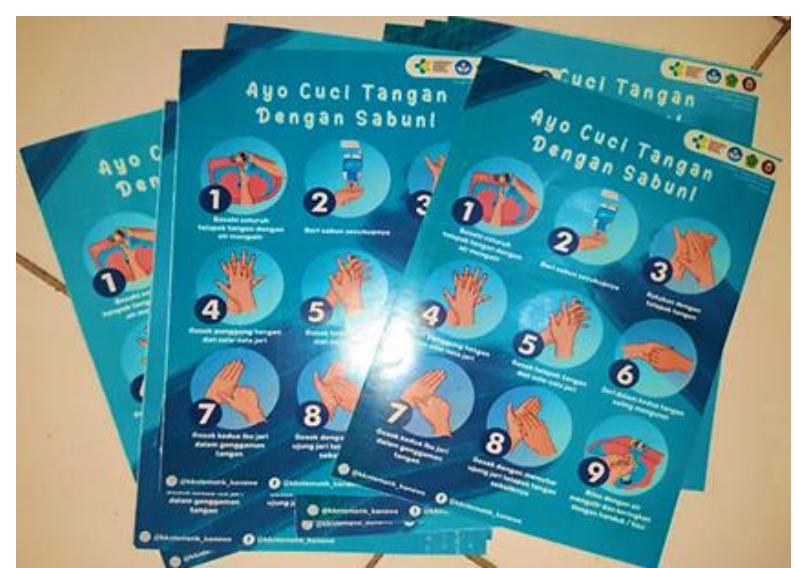

Gambar 6. Pemasangan Poster Langkah-langkah Mencuci Tangan Menurut WHO

Selain itu juga dilakukan pemasangan poster tentang pencegahan COVID-19 di 20 titik sarana umum. Poster ini berisi informasi tentang cara penularan dan pencegahan COVID-19 yang bertujuan untuk mengedukasi warga masyarakat tentang cara penularan COVID-19 dan langkah-langkah pencegahannya.

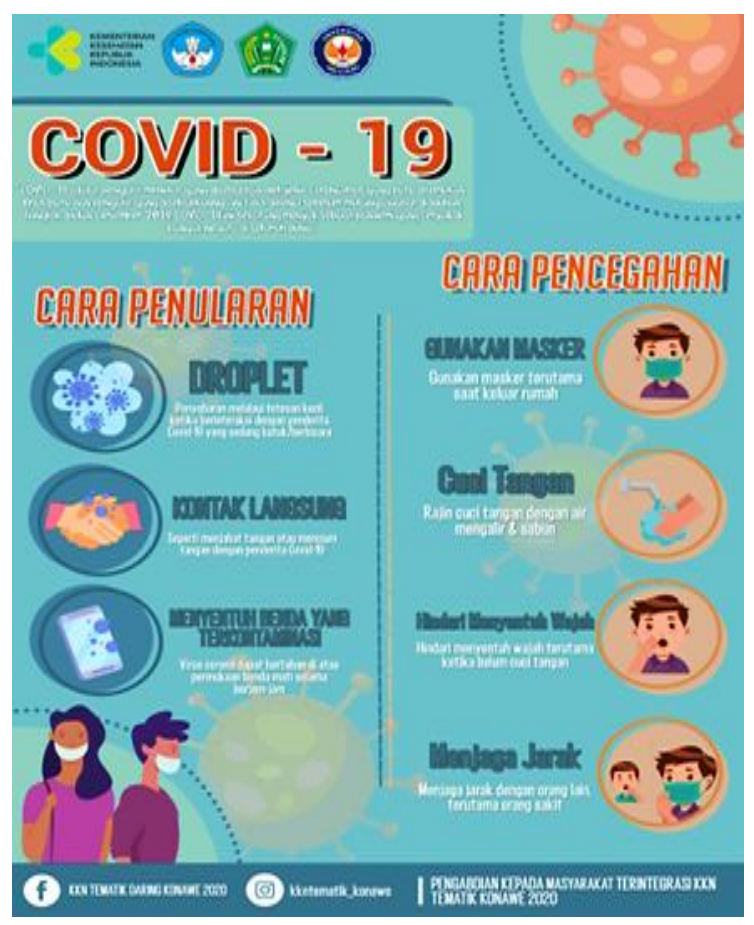

Gambar 7. Poster Pencegahan COVID-19

Poster New normal berisi tentang hal-hal yang harus dipersiapkan dalam menghadapi era kehiupan baru pasca pandemi COVID-19. Hal ini bertujuan untuk menginformasikan kepada warga masyarakat tentang persiapan di era tatanan hidup baru termasuk langkahlangkah yang ditempuh dalam menerapkan protokol kesehatan. Poster ini diserahkan sebanyak 20 buah ke Dinas Kesehatan Kabupaten Konawe untuk didistribusikan ke tempat-tempat umum.

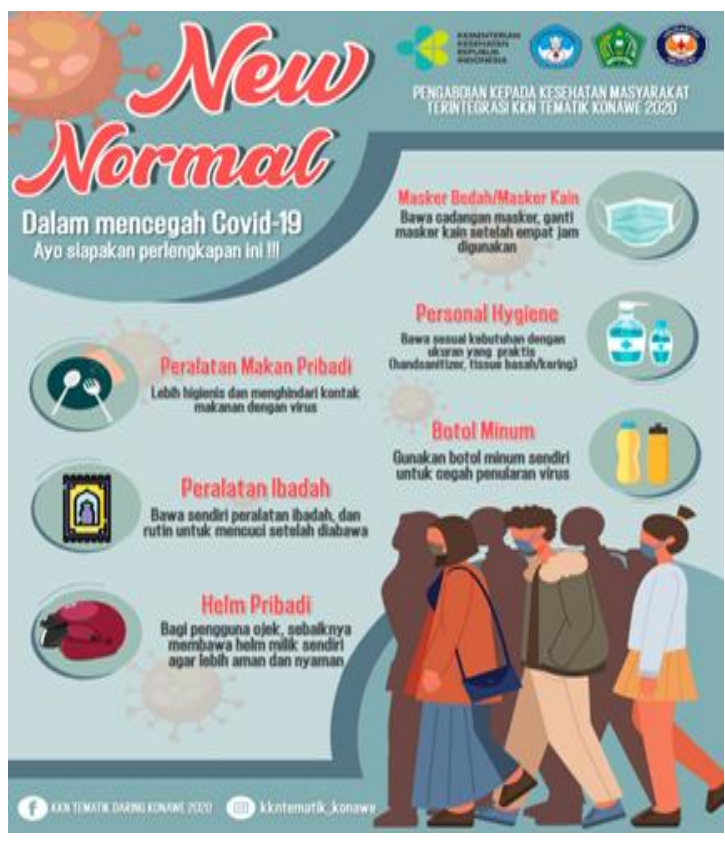

Gambar 8. Poster New Normal

Tahap evaluasi kegiatan dilakukan sebagai bagian akhir kegiatan edukasi melalui webminar dengan meminta kesediaan peserta untuk mengisi kuesioner yang berisi 20 pertanyaan yang mengukur pengetahuan tentang pencegahan COVID-19 dan penerapan protokol kesehatan. Terdapat lima topik yang ditanyakan yaitu: (1) bahaya dan tanda gejala COVID-19 (100\% peserta menjawab benar), (2) penggunaan hand sanitizer ketika beraktivitas di luar rumah dan mencuci tangan dengan air mengalir ( $93 \%$ peserta menjawab benar), (3) menjaga jarak ketika berada di tempat umum $(91 \%$ peserta menjawab benar, (4) lama waktu karantina mandiri setelah bepergian ke zona merah COVID-19 (67\% peserta menjawab benar), dan (5) Kebijakan pemerintah mengenai COVID-19 dan new normal (100\% peserta menjawab benar). Rata-rata pengetahuan peserta webminar dapat diketahui melalui hasil analisis jawaban 
tersebut. Sebanyak 86,96\% responden memiliki pengetahuan yang baik, dan terdapat 2 peserta $(2,9 \%)$ yang menjawab benar seluruh pertanyaan yang diberikan. Suatu media pembelajaran bisa dikatakan efektif ketika memenuhi kriteria, diantaranya mampu memberikan pengaruh, perubahan atau dapat membawa hasil (Yuliana, 2020). Kriteria lain yang digunakan sebagai indikator tercapainya tujuan kegiatan ini adalah terlaksananya seluruh rencana program kerja (100\%), ketekunan dalam mengikuti kegiatan webminar dengan persentase peserta yang hadir adalah lebih dari $90 \%$, serta keingintahuan dan pemahaman peserta terhadap materi seminar yang diberikan.

\section{KESIMPULAN}

Upaya meningkatkan pengetahuan masyarakat terkait pengendalian COVID-19 dan penerapan protokol kesehatan dapat dilakukan melalui edukasi berbasis media online. Hal ini sesuai dengan kebijakan physical distancing yang dianjurkan oleh pemerintah saat ini dan juga bentuk media yang dinamis dan virtual yang lebih memberikan daya tarik dan kemudahan pemahamanan bagi masyarakat, serta jangkauannya yang lebih luas. Pemberian edukasi juga ditunjang dengan pemasangan poster untuk memudahkan masyarakat memahami materi yang disampaikan. Hasil yang diperoleh dari kegiatan ini menunjukkan bahwa rata-rata tingkat pengetahuan masyarakat tentang pencegahan COVID19 dan protokol kesehatan di era new normal adalah baik. Hal ini juga dapat dilihat dari dukungan pemerintah Kab. Konawe dan masyarakat dalam mengikuti kegiatan edukasi. Disadari bahwa kegiatan PKM seperti ini sangat diperlukan bagi peningkatan pengetahuan dan kesadaran masyarakat sebagai upaya mencegah penyebaran COVID-19, sehingga perlu dilakukan edukasi yang kontinyu oleh pemerintah dan pihak terkait serta menggiatkan partisipasi masyarakat dalam penerapan protokol kesehatan di era new normal.

\section{UCAPAN TERIMA KASIH}

Terima kasih kepada LPPM Universitas Halu Oleo yang telah memberikan dukungan terhadap kegiatan ini melalui Anggaran DIPA Universitas Halu Oleo tahun 2020. Terima kasih juga kepada Pemerintah Daerah Kabupaten Konawe, Dinas Kesehatan dan Satgas COVID-19 Kabupaten Konawe sebagai mitra yang telah memfasilitasi pelaksanaan kegiatan pengabdian kepada masyarakat ini.

\section{REFERENSI}

Adha, A.Y., Wulandari, D.R., Himawan, A.B. 2016. Perbedaan Efektivitas Pemberian Penyuluhan Dengan Video Dan Simulasi Terhadap Tingkat Pengetahuan Pencegahan Tb Paru (Studi kasus di MA Husnul Khatimah Kelurahan Rowosari Kecamatan Tembalang Kota Semarang). Jurnal Kedokteran Diponegoro. 5(4):565-579. https://doi.org/10.14710/dmj.v5i4.14253

Dinas Kesehatan Provinsi Sulawesi Tenggara. 2020. Info COVID-19 Sultra. https:/ / dinkes.sultraprov.go.id/info-covid19-sultra/

Hanson, C., West, J., Neiger, B., Thackeray, R., Barnes, M., McIntyre, E. 2011. Use and Acceptance of Social Media Among Health Educators. American Journal of Health Education. 42(4):197204.

https://doi.org/10.1080/19325037.2011.10599 188

Jumilah, J., Jauhari, A.H., Ridha, A. 2014. Efektifitas Media Poster Terhadap Peningkatan Pengetahuan Tentang Kesehatan Gigi (Studi pada siswa-siswi kelas V SD Negeri di Kelurahan Saigon). Jumantik: Jurnal Mahasiswa dan Peneliti Kesehatan. 1(2):1-11. http://dx.doi.org/10.29406/jjum.v1i02.315

Kementerian Kesehatan Republik Indonesia. 2020. Pedoman Pencegahan dan Pengendalian Covid-19. 
Jakarta: Kementerian Kesehatan Republik Indonesia.

Kresna, A., Ahyar, J. 2020. Pengaruh physical distancing dan social distancing terhadap kesehatan dalam pendekatan linguistic. Jurnal Syntax Transformation.

1(4):14-19. https://doi.org/10.46799/jurnal\%20syntax\% 20transformation.v1i4.42

Muhyiddin. 2020. Covid-19, New Normal dan Perencanaan Pembangunan di Indonesia. Jurnal Perencanaan Pembangunan: The Indonesian Journal of Development Planning. 4(2):240-252.

https://doi.org/10.36574/jpp.v4i2.118

Ngadiran, A., Tambunan R., Sitorus, N., Saragih, B., Sariningsih, OD., Juliyanti, Akriani, M. 2020. Peningkatan kemandirian keluarga dalam adaptasi menghadapi kehidupan new normal. JPKMI (Jurnal Pengabdian Kepada Masyarakat Indonesia). $\quad$ 1(3): 186-194. https://doi.org/10.36596/jpkmi.v1i3.87

Notoatmodjo, S. 2003. Pendidikan dan Perilaku Kesehatan. Jakarta: Rineka Cipta.

Rosidi, A., Nurcahyo, E. 2020. Penerapan New Normal (Kenormalan Baru) Dalam Penanganan COVID-19 Sebagai Pandemi Dalam Hukum Positif. Journal Imiah Rinjani: Media Informasi Ilmiah Universitas Gunung Rinjani. 8(2):193-197.

Sampurno, M.B.T., Kusumandyoko, T.C., Islam, M.A. 2020. Budaya media sosial, edukasi masyarakat dan pandemic COVID-19. SALAM: Jurnal Sosial dan Budaya Syar-i. 7(6):529-542.

https:/ /doi.org/10.15408/sjsbs.v7i5.15210

Sari, N.P., Angelina, R., Fauziah, L. 2019. Pengaruh Edukasi melalui Media Video terhadap Pengetahuan dan Sikap Keluarga tentang Pneumonia pada Balita. Jurnal Ilmu Keperawatan Anak. 2(2):69-76. http://dx.doi.org/10.32584/jika.v0i0.357

Sukesi, T.W., Maurizka, I.R., Pratiwi, R.D., Kahar, M.V., Sari, D.A.P, Indriani, N.S., Santi. 2020. Peningkatan pengetahuan rumah sehat dengan metode ceramah dan leaflet di Dusun Modalan. Jurnal Pemberdayaan: Publikasi Hasil Pengabdian kepada Masyarakat. 4(2):183-190. https:/ /doi.org/10.12928/jp.v4i2.1961
Yuliana, Y. 2020. Analisis keefektifan pemanfaatan elearning sebagai media pembelajaran Pendidikan agama islam pada masa pandemic corona (Covid-19). Salam: Jurnal Sosial dan Budaya Syar-i. 7(10): 875-894. https://doi.org/10.15408/sjsbs.v7i10.17371 